\title{
ABOUT ELI-UNIDROIT RULES ADOPTION AND TRANSLATION INTO UKRAINIAN
}

\author{
Iryna Izarova \\ Tetyana Komarova \\ Yuliia Baklazhenko \\ https://doi.org/10.33327/AJEE-18-4.3-n000080
}

\begin{abstract}
he Model European Rules of Civil Procedure prepared by the European Law Institute with the International Institute for the Unification of Private Law during 2013-2021 have a great potential impact on the harmonisation of civil procedure and have attracted the attention of scholars from all over the world.
\end{abstract}

At the same time, Ukraine's European integration aspirations determine the scientific interest in the European legislation, as well as in current trends in its development, in particular, the harmonisation of European and domestic legislation of EU member states. In the field of civil procedure, this has led to the creation of a single comprehensive mechanism for the protection of rights in the Union: cross-border civil proceedings or EU civil proceedings. Its formation was the result of the evolution of the main civil procedural models of modern European states and their transformation under common market conditions. ${ }^{1}$

The creation of the EU and further European integration as a basis for the formation of the internal market of capital, goods, services, and labour necessitated the creation and provision of a common legal space. European standards of civil procedure, implemented through ECtHR decisions and Council of Europe law, have proved insufficient to meet the needs of the EU common market. ${ }^{2}$ This necessitated the harmonisation of the legislation of the EU member states. In particular, in the field of civil procedure, a supranational mechanism for regulating relations in civil and commercial cases of a cross-border nature, the European Civil Procedure, or the EU civil procedure, was established.

It cannot be said that immediately after the publication of the results of the project on the convergence of civil procedure in the EU, these ideas were adopted, and the civil process was immediately harmonised. Yet, the main provisions were implemented in the following years in EU legislation. ${ }^{3}$

Further harmonisation of civil proceedings in the EU is linked to the development of common regional rules of civil procedure. Such a project was launched in cooperation

1 I Izarova, Theory of EU Civil Procedure (Dakor 2015); see also A Uzelac, 'Towards the European Rules of Civil Procedure: Rethinking Procedural Obligations (I Izarova, A Kovtun, T Vakhoneva trans, eds)' (2018) 1 (106) Bulletin of Taras Shevchenko National University of Kyiv, Legal Studies 23-32; C H (Remco) van Rhee 'Towards Harmonised European Rules of Civil Procedure: Obligations of the Judge, the Parties and their Lawyers' (2020) 1(6) Access to Justice in Eastern Europe 6-33.

2 See, inter alia, M Storme, Approximation of Judiciary Law in the European Union (Kluwer 1994); M Storme, 'Improving Access to Justice in Europe' (2010) Teka Kom Praw - OL PAN 209, M Storme, 'A Single Civil Procedure for Europe: A Cathedral Builders' Dream' (2005) 22 Ritsumeikan Law Review <http://www.asianlii.org/jp/journals/RitsLRev/2005/6.pdf> accessed 27 July 2021.

3 See Regulations of European Small Claims Procedure, European Order for Payment Procedure and others, adopted since 2004 . 
with UNIDROIT and the newly established European Law Institute (ELI). Following the completion of a joint project to prepare the Principles for Transnational Civil Procedure, UNIDROIT plans to continue working in this direction. In particular, it was decided to focus on the regional level and adapt the Principles to the peculiarities of specific legal systems.

Launched in 2013, the project 'From Transnational Principles to European Rules of Civil Procedure' (hereinafter, Rules) ${ }^{4}$ marked a new stage in the development of civil procedural law in Europe. The theoretical basis of the Rules was the ALI-UNIDROIT Principles, the European Convention and the EU Charter of Fundamental Rights, general traditions of European countries, M. Storme's draft, the French Code of Civil Procedure, and other codes, EU Court and ECtHR judgments, and EU directives and regulations. This ensured the impact of the Rules on all states that are members of the EU and the Council of Europe, and therefore belong to European civilisation. Thus, the polycivilisation paradigm of the modern world, according to which the main unifying feature is the maintenance of the defining cultural values of the community, has ensured further convergence of EU law and the establishment of common traditions of European countries.

The main task of the Rules was to establish uniform principles of judicial proceedings, as, according to the authors of the project, they are aimed at avoiding fragmentary and unsystematic changes in European civil procedure law and are the first attempt to develop regional projects, taking into account regional legal cultures and rules. ${ }^{5}$ It should be noted that regionality as a defining feature of the members of such an association does not characterise them territorially: among the member states of the Council of Europe, there are those countries that are not located on the European continent.

The preparation of these Rules once again confirms the change of the social paradigm from the unification direction to the harmonisation of the civil process and the formation of its new modern concept in European countries. The significant weight and influence of the Principles of Transnational Civil Procedure on the development of civil procedural law in European countries, the successful implementation of M. Storm's ideas, and the formation of the EU civil procedure system ensured the overall success of harmonisation processes in the EU. ${ }^{6}$ At the same time, the question of the scope of application of regional rules of civil procedure is becoming extremely important, and discussions on the need to extend the EU civil process to internal disputes are moving to a new level.

Regional rules of civil procedure are designed to define common requirements and rules governing relations for the consideration and resolution of civil and commercial cases of a cross-border nature with the participation of residents of different states of one regional association. This is extremely important to protect common market participants and economic relations within its limits.

The introduction of common European rules of civil procedure and their application to the settlement of cross-border disputes on a general basis is an important area of convergence of civil proceedings in the EU. Taking into account the latest achievements of the science

4 Model European Rules of Civil Procedure (with the International Institute for the Unification of Private Law, UNIDROIT) <https://www.europeanlawinstitute.eu/projects-publications/completedprojects-old/completed-projects-sync/civil-procedure/> accessed 24 July 2021.

5 Initial report on the ELI-UNIDROIT 1st Exploratory Workshop <https://www.europeanlawinstitute. eu/fileadmin/user_upload/p_eli/Projects/ELI-UNIDROIT_Workshop_initial_report.pdf> accessed 24 July 2021.

6 See the report submitted to the the European Parliament's Committee on Legal Affairs, which was submitted to the Commission on common minimum standards of civil procedure in the EU <https:// www.europarl.europa.eu/doceo/document/A-8-2017-0210_EN.html?redirect\#title2> accessed 24 July 2021, and the Study Common minimum standards of civil procedure: European Added Value Assessment <https:/www.europarl.europa.eu/RegData/etudes/STUD/2019/642804/EPRS_ STU(2019)642804_EN.pdf> accessed 24 July 2021. 
of civil procedural law will ensure further development of European integration and improvement of national systems of civil procedure, but the regulation of internal disputes through regional rules at the present stage of political and economic relations can hardly be considered appropriate.

On this occasion, AJEE warmly invites proposals for a special topic to be published in the upcoming year's issues. The main focus of the proposal should cover the ELI Model Rules and various aspects of its further adaptation in national and European law. These contributions will be published free of charge after a careful evaluation and review. ${ }^{7}$

For Ukraine, as well as for other EU entrance candidate countries, these Rules are an opportunity to harmonise the national civil process with EU law and create the necessary basis for the adaptation of European law and EU membership. Accession to the true European area of justice for Ukraine is an extremely important direction, as the introduction of general principles of civil justice will provide an opportunity to ensure effective protection of rights and eliminate differences in the domestic procedural system.

The movement and translation of law is a dynamic process involving diffusion and translation $^{8}$. In view of this, the participation in the preparation of Model European Rules of Civil Procedure and, in particular, their official translation into Ukrainian, which will be carried out under the guidance of Prof. Iryna Izarova, is a relevant issue. Achieving maximum objectivity while creating the Ukrainian text of the Rules must be implemented by thorough regulation of the translation process, establishing methodological basis of translation, careful choosing sources of reference and step-by-step expert control over the quality of translation.

The organization of translation is in line with the officially approved procedure of legal translation. In particular, to address the issue of translation of acquis communautaire, The Ministry of Justice of Ukraine approved the order of translation ${ }^{9}$, which serves as guidelines for the current work. Thus, the translation process includes the following stages: translation of the latest version of the Rules, professional expertise, terminological expertise, editing of the target language (Ukrainian) text.

To properly implement this task, a scientific council has been formed, which includes leading Ukrainian scientists and specialists in the field of civil procedure. The largest professional association of specialists-editors in Ukraine - the Association of Ukrainian Editors has also been involved. Moreover, in order to methodologically support the translation process, ensure terminological consistency and uniformity, a terminological English-Ukrainian glossary of Model Rules of Civil Procedure is being compiled in parallel with the translation process.

Establishing methodological basis of translation and careful choosing sources of reference is another important condition for quality translation. The task is even more difficult in light of the absence of the Ukrainian language in the plethora of resources for translators of the EU. Nevertheless, the list of these resources is well worth consulting, due to the fact that it contains translations in the Polish language, linguistically close to the Ukrainian one, and into German language, terminology of which is approximated with the continental law system. The mentioned list of resources includes publicly accessible full-text database of

$7 \quad$ The deadline for submitting the abstracts is 1 October 2021. After the evaluation of the proposals, the full-length manuscripts should be submitted by 1 December 2021, upon invitation of AJEE.

8 B Brake, PJ Katzenstein, 'Lost in Translation? Nonstate Actors and the Transnational Movement of Procedural Law’ (2013) 67 (4) International Organization 725-757 <www.jstor.org/stable/43282085> accessed 27 July 2021.

9 The Order of Translation of European Acquis Communautaire No 144/5 of 26 November $2003<$ https:// zakon.rada.gov.ua/laws/show/z1081-03\#Text> accessed 27 July 2021. 
EU law EUR-Lex, the database of EU terminology IATE, the multilingual wide-coverage thesaurus EuroVoc and other resources for translators. EUR-Lex provides free access to European Union law and other documents considered to be public, written in all 23 official EU languages. The IATE website (Inter-Active Terminology for Europe) gives access to a database of EU inter-institutional terminology. EuroVoc is a multi-disciplinary thesaurus covering fields that are sufficiently wide-ranging to encompass both Community and national points of view ${ }^{10}$. The preferred order for terminology search is determined by the European Commission in recommendations on linguistic resources use. It includes (in the order of relevance): IATE, EUR-Lex (existing legislation), General reference sources, professional literature ${ }^{11}$. Thus, these resources constitute the main sources of reference in the process of translation of the Rules.

To disseminate the results of this work, several webinars are planned with the involvement of experts and members of the Working Groups for the preparation of the Rules, where the features of the proposed approaches, the benefits of certain mechanisms, and the possibility of applying such experience to reform Ukrainian civil procedure will be discussed in detail.

The translation of this work, which is more than 400 pages, will be a serious challenge for translation specialists and editors. On behalf of all our team, let us express our sincere hope that this work will be useful to all those who are interested in civil proceedings, developing the science of civil procedural law, and reforming civil procedural legislation!

10 R Steinberger, A Eisele, S Klocek, S Pilos, P Schlüter, 'DGT-TM: A freely Available Translation Memory in 22 Languages' in Proceedings of the Eighth International Conference on Language Resources and Evaluation (LREC'12) (May, 2012) < http://www.lrec-conf.org/proceedings/lrec2012/pdf/814_Paper. pdf $>$ accessed 27 July 2021.

11 European Commission, 'Explanatory notes for PL translation' (20 February 2009) <https://ec.europa. eu/info/files/polish-resources-how-use-polish-linguistic-resources_en> accessed 27 July 2021. 